\title{
First Signs of Spring
}

\section{By DOUG GILRO: , R.R. 2, Regina}

The scene on the front cover is a small portion of Boggy Creek. The time is late March. This creek is typical of hundreds of other streams that wind their way across the prairies.

Usually in March the creek begins to open in places where there are springs and never actually froze too hard at any time during the winter, but just back around the bend the ice is still two feet thick.

Each day as the sun rises higher its rays grow stronger; the winds no longer possess the icy sting of winter but seem to have taken on a softer warmth. The snow on the slopes and in the surrounding fields begins to melt at a surprisingly rapid rate. Gurgling water comes hurrying down natural drainage systems and soon spills out onto the frozen surface of the creek.

At first this water lies quietly in flooded condition then as more is teadily added it suddenly breaks free and the small peaceful stream of summer has now become a rushing torrent.

What a pleasure it is when we go outside in the twilight hours of a spring evening and just stand there breathing in the sweet spring smells. From down at the creek comes the steady serenade of rushing water. We find ourselves listening for another that is almost bound to come and then sure enough there it is the clear, sweet call of the Kildeer Plover. From down in the elm grove comes another voice heard above the sound of rushing water, deep and mysterious - whoo! whoo! whoo! tis the voice of the Great-Horned Owl.

Fortunate indeed are the people who can watch a prairie stream awaken from its winter sleep.

\section{Nature's Blessing}

John A. Popoff, Yorkton

I love the little birds and bees,

I love the flowers and the trees,

I love the grass and love the sky,

I love the people living by.

My heart is open to each thing,

Be it on foot or on the wing;

It will accept with equal zest

The things with which this world is blest.

I love the rivers and the hills, The valleys, creeks and tiny rills, The oceans deep and mountains wide, The creatures living by their side.

Good Mother Nature in her way Has given us the night and day, Has planted in the azure sky The friendly moon and sun on high;

Provided us with eyes to see The wonders of her symmetry, And filled us full of heart and mind As well befits our humankind.

May we, with blessings so endowed, Proclaim our love for them aloud; We'll find it meets our every need. To live our love in word and deed.

\section{The Faith of a Jack Rabbit}

William E. Jasper, Struan, Sask.

I was walking beside my wagon one evening, juist as it was starting to get dark. I could hear some other teams coming along behind. Then, like a streak, a half-grown Jack Rabbit passed me, followed some five or six rods behind by three hungry hounds in hot pursuit. Soon they were all out of sight ahead of us. Ten or fifteen minutes later, back they came. But this time the hounds were within a few feet of the poor rabbit. It was just about exhausted. He knew there was only one hope in the world left for his life. That hope was me. Would he reach me before the dogs got him? He put every ounce of strength into those last few feet, but alas, he was one second too late! Before I could reach down and grab him up, the hounds had him. Doesn't this prove that even these wild creatures know, deep down in their hearts, that we have a God-given responsibility to protect them in a time of great need? 